\title{
Control of Product Formation During Glucose Fermentation by Bacillus macerans
}

\author{
By P. J. WEIMER \\ Central Research and Development Department, E. I. du Pont de Nemours and Company \\ Experimental Station, Wilmington, Delaware 19898, USA
}

(Received 17 May 1983; revised 8 August 1983)

\begin{abstract}
The anaerobic fermentation of glucose by Bacillus macerans ATCC 7068 was studied in batch culture with and without $\mathrm{pH}$ control. The fermentation was characterized by two distinct metabolic phases. In the primary growth phase, the concentrations of ethanol and acetic acid increased exponentially, and formate was detected as a minor product. The secondary phase was marked by a slowing and eventual cessation of growth, along with the disappearance of formate and acetate, and the appearance of $\mathrm{H}_{2}, \mathrm{CO}_{2}$, and acetone. Exogenously-added substrates were converted with stoichiometries of 1 formate $\rightarrow 1 \mathrm{H}_{2}+1 \mathrm{CO}_{2}$, and approximately 2 acetate $\rightarrow 1$ acetone. Consumption of $>8 \mathrm{~g}$ glucose $1^{-1}$ required exogenous $\mathrm{pH}$ control, and acetone formation was strongly $\mathrm{pH}$-dependent. Glucose was fermented by the Embden-Meyerhof pathway. Cell extracts contained pyruvate formate-lyase and formate dehydrogenase activities, but only low pyruvate dehydrogenase activity. A balanced fermentation pathway is presented which is consistent with reaction stoichiometries and $\left[{ }^{14} \mathrm{C}\right]$ glucose labelling data in whole cultures, and with enzyme activities in extracts. The pathway is compared with those of other facultative anaerobes and the acetone-producing Clostridium acetobutylicum.
\end{abstract}

\section{INTRODUCTION}

The anaerobic fermentation of carbohydrates by Bacillus macerans was first described by Schardinger (1905). In contrast to the well-known acetone/butanol fermentation of Clostridium acetobutylicum, the Bacillus fermentation produces ethanol as the chief reduced product, with acetone, $\mathrm{H}_{2}$, and $\mathrm{CO}_{2}$, but not $\mathrm{n}$-butanol, as co-products. Subsequent work by Northrop et al. (1919), and by Arzberger et al. (1920) on a similar organism, 'B. acetoethylicus', demonstrated that formate and acetate were transient fermentation products, and that formation of acetone occurred only late in the fermentation and was enhanced by low culture $\mathrm{pH}$. The physiology and biochemistry of acetone-producing Bacillus strains have received relatively little attention (Speakman, 1925; Prescott \& Dunn, 1959).

The purpose of the present study was to examine in more detail the product formation during glucose fermentation, particularly with regard to the effect of $\mathrm{pH}$ control and the involvement of specific enzymes in the catabolic pathway.

\section{METHODS}

Materials. All chemicals were reagent grade, obtained from either Sigma or Fisher (Fair Lawn, N.J., U.S.A.). Enzymes used for coupled enzymic assays were obtained from Sigma. Anaerobic grade $\mathrm{N}_{2}$ was purchased from Union Carbide-Linde Division (Somerset, N.J., U.S.A.). $\left[{ }^{1+} \mathrm{C}\right]$ Glucose specifically labelled in the C-1, C-3,4 or C-6 positions was obtained from New England Nuclear.

Organism and growth conditions. Bacillus macerans ATCC 7068 was obtained from the American Type Culture Collection. According to Gordon et al. (1973), this strain is identical to 'B. acetoethylicus' described by Northrop et al. (1919). The organism was grown in CM5 medium which contained (1-1): $\mathrm{KH}_{2} \mathrm{PO}_{4}, \mathbf{0} \cdot 26 \mathrm{~g} ; \mathrm{Na}_{2} \mathrm{HPO}_{4} .7 \mathrm{H}_{2} \mathrm{O}$, $2 \cdot 17 \mathrm{~g} ;\left(\mathrm{NH}_{4}\right)_{2} \mathrm{SO}_{4}, 1.98 \mathrm{~g} ; \mathrm{MgCl}_{2} .6 \mathrm{H}_{2} \mathrm{O}, 0.20 \mathrm{~g} ; \mathrm{CaCl}_{2}, 0.025 \mathrm{~g}$; yeast extract, $2.0 \mathrm{~g}$; mineral solution, $2.0 \mathrm{ml}$. The mineral solution contained (mg 1-1): $\mathrm{Na}_{2}$ EDTA, $400 ; \mathrm{MnSO}_{4} .4 \mathrm{H}_{2} \mathrm{O}, 340 ;\left(\mathrm{NH}_{4}\right)_{6} \mathrm{Mo}_{7} \mathrm{O}_{24} \cdot 4 \mathrm{H}_{2} \mathrm{O}, 400$; $\mathrm{FeSO}_{4} .7 \mathrm{H}_{2} \mathrm{O}, 800: \mathrm{CoCl}_{2}, 6 \mathrm{H}_{2} \mathrm{O}, 40 ; \mathrm{NiCl}_{2} .6 \mathrm{H}_{2} \mathrm{O}, 20 ; \mathrm{ZnSO}_{4} \cdot 7 \mathrm{H}_{2} \mathrm{O}, 20 ; \mathrm{CuSO}_{4}, 2$. 
Unless otherwise indicáted, all incubations were carried out at $43^{\circ} \mathrm{C}$, using the anaerobic culture technique of Balch \& Wolfe (1976), except that $\mathrm{N}_{2}$ ( $1 \mathrm{~atm}$ ) was used as gas phase, and no reducing agents were added to the medium. Experiments were performed in $18 \times 150 \mathrm{~mm}$ anaerobic tubes (Bellco Glass, Vineland, N.J., U.S.A.) containing $10 \mathrm{ml}$ of medium, or in a 21 Multigen fermenter (New Brunswick Scientific Co.). Addition of primary growth substrates or effectors was made using sterile plastic hypodermic syringes.

Analysis of products. Solvents, alcohols, and volatile acids were analysed by GLC. Samples were prepared by adding $1 \mathrm{ml}$ of culture to chilled microcentrifuge tubes, centrifuging for $2 \mathrm{~min}$ in a Beckman microcentrifuge, and adding $100-400 \mu \mathrm{l}$ of supernatant to vials containing $0.33 \mathrm{M}-\mathrm{H}_{3} \mathrm{PO}_{4}$ to give a total volume of $800 \mu \mathrm{l}$. Samples were injected into a Hewlett-Packard $5880 \mathrm{~A}$ gas chromatograph equipped with a model $7672 \mathrm{~A}$ automatic liquid sampler. The following chromatographic conditions were used: column, $1.8 \mathrm{~m} \times 0.32 \mathrm{~cm}$ (o.d.) Teflon-lined stainless steel packed with $10 \% \mathrm{SP} 1200 / 1 \% \mathrm{H}_{3} \mathrm{PO}_{4}$ on Chromosorb W/AW (Supelco, Bellefonte, Pa., U.S.A.); carrier gas, He at $18 \mathrm{ml} \mathrm{min}^{-1}$; injector temperature, $200^{\circ} \mathrm{C}$; flame ionization detector temperature, $200^{\circ} \mathrm{C}$; oven temperature programme, isothermal at $50^{\circ} \mathrm{C}$ for $2.5 \mathrm{~min}$, followed by heating at $15^{\circ} \mathrm{C} \mathrm{min}^{-1}$ for $6 \mathrm{~min}$, then holding at $140^{\circ} \mathrm{C}$ for $1.5 \mathrm{~min}$. Under these conditions the following retention times were obtained (min): acetaldehyde, 0.75 ; acetone, 1.3; ethanol, 1.6; iso-propanol, 1.9; methyl ethyl ketone, 3.0 ; n-propranol, 3.8 ; $n$ butanol, 5.6; acetic acid, 6.4; butyric acid, 7.8. Lower limits for detection of these compounds were 0.02-0.06 mM.

$\mathrm{H}_{2}$ and $\mathrm{CO}_{2}$ were analysed essentially by the procedure of Nelson \& Zeikus (1974). Corrections were made for dissolved gases using Henry's Law; unless otherwise indicated $\mathrm{CO}_{2}$ is expressed as the total of all species $\left(\mathrm{CO}_{2}\right.$, $\mathrm{HCO}_{3}{ }^{-}, \mathrm{CO}_{3}^{2}{ }^{-}$), calculated from $\mathrm{pH}$-dependent bicarbonate equilibrium data. Reducing sugars were determined by the dinitrosalicylic acid method of Miller et al. (1960). Cell growth was usually monitored turbidimetrically at $525 \mathrm{~nm}$. Cell dry weight was measured by first filtering $20-50 \mathrm{ml}$ of culture through tared $47 \mathrm{~mm} \times 0.4 \mu \mathrm{m}$ pore size polycarbonate membranes (Nucleopore, Pleasanton, Cal., U.S.A.), and then drying to constant weight at $100{ }^{\circ} \mathrm{C} .{ }^{14} \mathrm{CO}_{2}$ was determined by injecting gas phase samples into Oxifluor- $\mathrm{CO}_{2}$ (New England Nuclear) followed by subsequent counting in a Packard 3255 liquid scintillation spectrometer. Protein was measured by the Lowry method, using bovine serum albumin as a standard.

pH studies. Batch culture pH studies were carried out in a New Brunswick Multigen fermenter. An overnight tube culture (approx. $10 \mathrm{ml}$ ) of $B$. macerans was inoculated into $1.51 \mathrm{~N}_{2}$-gassed CM5 containing $45 \%$ (w/v) glucose. After inoculation, $\mathrm{N}_{2}$-gassing was discontinued and stirring maintained at 100 r.p. m. Gas leaving the fermenter was channelled through a $25 \mathrm{~cm}$ condenser mounted vertically on top of the fermenter. The condenser fluid was maintained at $5^{\circ} \mathrm{C}$ using a Brinkmann-Lauda (Westbury, N.Y., U.S.A.) RM3 refrigerated circulator. During the fermentation, the lower culture $\mathrm{pH}$ was regulated by automatic addition of $5 \mathrm{M}-\mathrm{NaOH}$. Antifoam B (Sigma) was added manually at 8-16 h intervals to reduce the large amounts of foam produced in agitated cultures.

Preparation of cell extracts. Frozen cell paste $(1.5 \mathrm{~g})$ was suspended in $3.0 \mathrm{ml} \mathrm{N}$-gassed $50 \mathrm{~mm}$-phosphate buffer, $\mathrm{pH} 7 \cdot 0$, containing $2 \mathrm{~mm}$-DTT. The suspension was passed two or three times through a cold $\left(4^{\circ} \mathrm{C}\right)$ French pressure cell (American Instrument Co., Silver Spring, Md., U.S.A.) at approximately $138 \mathrm{MPa}\left(20000 \mathrm{lbf}^{-2}\right.$ in. The resulting mixture was gassed briefly with $\mathrm{N}_{2}$ and centrifuged at $23000 \mathrm{~g}$ for $90 \mathrm{~min}$. The supernatant was transferred via syringe to sealed vials containing a $N_{2}$ gas phase. This supernatant ('cell extract') was kept on ice and used immediately for enzyme assays.

Enzyme assays. Spectrophotometric assays were performed using a hybrid Gilford 240/Beckman DU UVvisible spectrophotometer. Assays were done at $43^{\circ} \mathrm{C}$ in $1.3 \mathrm{ml}$ cuvettes sealed with soft rubber stoppers. Cuvettes contained $1 \mathrm{ml}$ of reaction mixture and a $\mathrm{N}_{2}$ gas phase. Various buffers were used, including Tris, $\mathrm{pH} 8 \cdot 7$; sodium/ potassium phosphate, $\mathrm{pH} \mathrm{7.0;} \mathrm{or} \mathrm{MES,} \mathrm{pH} 5 \cdot 7$.

Formate dehydrogenase (EC 1.2.1.2) was assayed by measuring the reduction of methyl viologen at $578 \mathrm{~nm}$ or of NAD or NADP at $340 \mathrm{~nm}$. Cuvettes contained $95 \mathrm{~mm}$-buffer, $10 \mathrm{~mm}$-electron acceptor, $2-30 \mu \mathrm{g}$ of extract protein and, in the case of the viologen, sufficient $\mathrm{Na}_{2} \mathrm{~S}_{2} \mathrm{O}_{4}$ to render the solution pale blue. The reaction was initiated by addition of $5 \mathrm{mM}$-sodium formate. Hydrogenase (EC 1.18.3.1) was assayed similarly, except that $0.40 \mathrm{ml}$ of $\mathrm{H}_{2}$ was used instead of formate to initiate the reaction. Benzyl viologen was also used as electron acceptor in some assays.

Formic hydrogen lyase (EC 1 2 . 1 . 1) was assayed by polarographic measurement of $\mathrm{H}_{2}$ production (Sweet et al., 1980) following addition of $10 \mathrm{~mm}$-sodium formate to reaction mixtures that contained (in $1.5 \mathrm{ml}$ ) $100 \mathrm{mM}$-MES, pH 5·7-6.0, $2 \mu \mathrm{g}$ extract protein, and various electron carriers, including NAD, methyl viologen, benzyl viologen, or horse heart cytochrome $c$.

Pyruvate formate-lyase (EC 2.3.1.54) was assayed by coupling the reaction to formate dehydrogenase and measuring the reduction of NAD at $340 \mathrm{~nm}$. Cuvettes contained $90 \mathrm{~mm}$-buffer, $1 \mathrm{~mm}-\mathrm{NAD}, 1 \mathrm{~mm}-\mathrm{CoA}, 7 \mathrm{~mm}-$ $\mathrm{KAsO}_{3}, 2$ units of Clostridium kluyveri phosphotransacetylase (EC 2.3.1.8), 5 mM-DTT, 1 unit Pseudomonas oxalaticus formate dehydrogenase (EC 1.2.1.2), and $2-30 \mu \mathrm{g}$ extract protein. The reaction was initiated by addition of 10 mM-sodium pyruvate.

Pyruvate dehydrogenase (EC 1.2.4.1) was assayed as for pyruvate formate-lyase, except that formate dehydrogenase was omitted. Occasionally, methyl viologen replaced NAD or NADP, and the absorbance changes during the reaction were measured at $578 \mathrm{~nm}$. 


\section{RESULTS}

\section{Product formation during carbohydrate fermentation}

Bacillus macerans ATCC 7068 fermented a wide variety of carbohydrates for growth, including monohexoses (glucose, fructose, mannose, galactose), dihexoses (maltose, cellobiose, sucrose, lactose, trehalose, melibiose), and trihexoses (melezitose, raffinose), as well as xylose, mannitol, starch, and xylan. Cellulose, xylitol, and sorbitol were not fermented. Fermentation of glucose $(0.5 \%, \mathrm{w} / \mathrm{v})$ in tube cultures resulted in the following reaction stoichiometry (mean value of three experiments after $6 \mathrm{~d}$ incubation): 1 glucose $\rightarrow 1.2$ ethanol +0.4 acetone +0.1 acetic acid $+1.8 \mathrm{H}_{2}+2.3 \mathrm{CO}_{2}$. The fermentation was balanced with respect to both electrons $[\mathrm{O} / \mathrm{R}$ index $($ Wood, 1961$)=0.93$ ] and carbon recovery $(102 \%)$. An ethanol/acetone ratio of $2 \cdot 2-3 \cdot 8$ was observed for all carbohydrates tested and varied slightly among substrates. The following compounds were not detected as products of glucose fermentation: methanol, isopropanol, $\mathrm{C}_{3}-\mathrm{C}_{6}$ volatile acids or alcohols, $\mathrm{C}_{2}-\mathrm{C}_{4}$ diols, lactic acid, methyl ethyl ketone, diacetyl, or acetoin. $n$-Butanol was not detected as a product, even when n-butanal or n-butyrate were added as substrates.

Carbohydrate fermentations usually stopped when the culture $\mathrm{pH}$ dropped to approximately 4.9 , regardless of the initial culture $\mathrm{pH}$ within a range of 6.0-8.5. Net carbohydrate consumption in these cultures was always within the range $3-8 \mathrm{~g} \mathrm{I}^{-1} \cdot \mathrm{CaCO}_{3}$ increased the extent of glucose utilization and product (especially ethanol) formation (Table 1). $\mathrm{NaOH}$ was also effective in stimulating the extent of glucose utilization.

A time course of product formation (Fig. 1) revealed an initial primary metabolic phase during which cell material, ethanol, and acetate concentrations increased at an exponential rate, and $\mathrm{pH}$ decreased from 6.8 to a preset lower limit of $5 \cdot 0$. During this phase, formic acid, and occasionally acetaldehyde, were detected transiently in the culture supernatants, reaching maximum concentrations of 5.4 and $0.8 \mathrm{mM}$, respectively after $20 \mathrm{~h}$ incubation. This growth phase was followed by a secondary metabolic phase marked by a slowing and eventual cessation of growth, continued ethanol production, a decrease in formic and acetic acid concentrations, and the appearance of $\mathrm{H}_{2}, \mathrm{CO}_{2}$, and acetone.

The disappearance of formate during stationary phase, and the late appearance of $\mathrm{H}_{2}$ and $\mathrm{CO}_{2}$, suggested a cleavage of a formate intermediate. Addition of 0,350 , or $500 \mu$ mol sodium formate to tube cultures $(10 \mathrm{ml})$ growing on $280 \mu \mathrm{mol}$ glucose plus $100 \mu \mathrm{mol} \mathrm{CaCO}_{3}$ resulted in accumulation of 470,849 , or $970 \mu \mathrm{mol} \mathrm{H}_{2}$ and 803,1251 , or $1341 \mu \mathrm{mol} \mathrm{CO}$, respectively.

The transient appearance of acetate prior to acetone production suggested that acetate serves as an intermediate in acetone formation. Addition of sodium acetate to tube cultures growing on glucose increased the extent of glucose consumption due to $\mathrm{pH}$ buffering, which resulted in a more complete utilization of glucose before the fermentation reached the minimum $\mathrm{pH}$ for catabolic activity ( $\mathrm{pH} 4 \cdot 9-5 \cdot 1)$. Addition of sodium acetate also resulted in a preferential

Table 1. Effect of $\mathrm{CaCO}_{3}$ and sodium acetate on glucose consumption and solvent formation by B. macerans

Cultures were grown for $6.8 \mathrm{~d}$ on CM 5 medium containing $2 \%$ glucose and $0.2 \%$ yeast extract. Results are expressed as mean values from triplicate cultures.

\begin{tabular}{|c|c|c|c|c|c|c|}
\hline \multirow[b]{2}{*}{ Effector } & \multirow{2}{*}{$\begin{array}{l}\text { Glucose } \\
\text { consumed } \\
(\mathrm{mM})\end{array}$} & \multirow[b]{2}{*}{$\begin{array}{c}\text { Final } \\
\mathrm{pH}\end{array}$} & \multicolumn{2}{|c|}{ Product formed } & \multirow[b]{2}{*}{$\begin{array}{c}\text { Gas phase } \mathrm{CO}_{2} \\
(\mathrm{mmol})\end{array}$} & \multirow[b]{2}{*}{ Ethanol/acetone } \\
\hline & & & $\begin{array}{l}\text { Acetone } \\
\text { (mM) }\end{array}$ & $\begin{array}{c}\text { Ethanol } \\
\text { (mM) }\end{array}$ & & \\
\hline None & 31 & $5 \cdot 1$ & 12 & 44 & $0 \cdot 7$ & $3 \cdot 6$ \\
\hline $\begin{array}{l}\mathrm{CaCO}_{3} \\
(100 \mathrm{mM})\end{array}$ & 93 & $5 \cdot 8$ & 22 & 132 & $2 \cdot 4$ & $6 \cdot 1$ \\
\hline $\begin{array}{l}\text { Sodium acetate } \\
(24 \mathrm{mM})\end{array}$ & 78 & $5 \cdot 7$ & 43 & 85 & $1 \cdot 5$ & $2 \cdot 0$ \\
\hline $\begin{array}{l}\mathrm{CaCO}_{3}+ \\
\text { sodium acetate }\end{array}$ & 104 & $6 \cdot 1$ & 40 & 154 & $2 \cdot 1$ & 3.9 \\
\hline
\end{tabular}




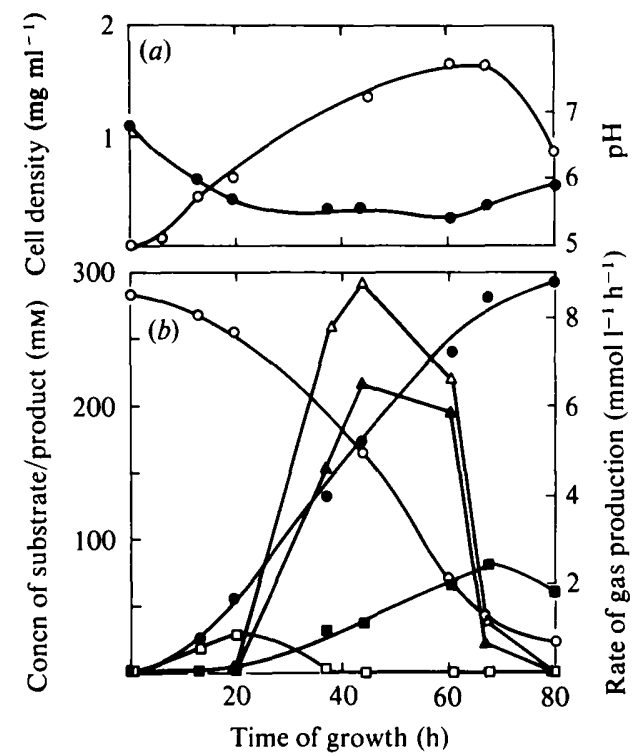

Fig. 1. Time course of product formation by $B$. macerans grown in a 121 fermenter that contained 101 CM5 medium plus $500 \mathrm{~g}$ glucose. Control of $\mathrm{pH}$ was achieved by automatic metered addition of $\mathrm{NaOH}$. (a) Cell density $(\mathrm{O}), \mathrm{pH}(\mathrm{O})$. (b) Residual glucose concentration $(\mathrm{O})$; accumulated concentration of ethanol (O), acetate $(\square)$, and acetone $(\square)$; instantaneous rate of $\mathrm{CO}_{2}(\Delta)$ and $\mathrm{H}_{2}(\Delta)$ production. The transient appearances of formate and acetaldehyde are not indicated.

Table 2. Effect of acetate addition on glucose fermentation by B. macerans

Cultures were grown for $5.8 \mathrm{~d}$ in CM5 medium containing $2 \%$ glucose and $0.2 \%$ yeast extract. Results are expressed as mean values of duplicate cultures.

\begin{tabular}{|c|c|c|c|c|c|c|c|}
\hline \multicolumn{2}{|c|}{ Acetate (mM) } & \multicolumn{4}{|c|}{ Product concentration (mM) } & \multirow[b]{2}{*}{$\begin{array}{l}\text { Acetate consumed/ } \\
\text { acetone formed }\end{array}$} & \multirow[b]{2}{*}{$\begin{array}{c}\text { Final } \\
\mathrm{pH}\end{array}$} \\
\hline Added & Consumed* & $\begin{array}{c}\mathrm{CaCO}_{3}(\mathrm{mM}) \\
\text { added }\end{array}$ & Acetone & Ethanol & $\begin{array}{l}\text { Ethanol/ } \\
\text { acetone }\end{array}$ & & \\
\hline 0 & - & 100 & 24 & 137 & $5 \cdot 8$ & - & $5 \cdot 7$ \\
\hline 12 & 10 & 100 & 31 & 125 & $4 \cdot 0$ & $1 \cdot 4$ & 5.8 \\
\hline 24 & 25 & 100 & 32 & 112 & $3 \cdot 5$ & $3 \cdot 0$ & 5.8 \\
\hline 48 & 39 & 100 & 36 & 116 & $3 \cdot 2$ & $3 \cdot 1$ & 5.9 \\
\hline 100 & 40 & 100 & 38 & 108 & $2 \cdot 9$ & $2 \cdot 8$ & $6 \cdot 1$ \\
\hline 48 & 36 & - & 44 & 88 & 1.9 & 1.8 & 5.9 \\
\hline
\end{tabular}

- Corrected for acetate concentration produced in control tubes without added acetate.

increase in acetone accumulation, and reversed the preferential ethanol production directed by $\mathrm{CaCO}_{3}$ (Table 1). The increase in acetone accumulation observed after addition of sodium acetate exhibited a stoichiometry of $2.4 \pm 0.8$ acetate consumed per acetone formed (Table 2). Although acetate addition stimulated final acetone yield, it did not hasten the onset of acetone synthesis.

\section{Effect of $\mathrm{pH}$ control on product formation}

The observation that acetone production occurred only late in the fermentation after $\mathrm{pH}$ had declined, along with the preferential ethanol production observed during $\mathrm{pH}$ control with $\mathrm{CaCO}_{3}$, suggested that an early event in the fermentation, related to a lowering of culture $\mathrm{pH}$, was required to induce acetone synthesis.

The effect of $\mathrm{pH}$ on product formation was further investigated in 1.51 batch culture containing $4-5 \%(\mathrm{w} / \mathrm{v})$ glucose. An initial $\mathrm{pH}$ of 6.8 (occasionally higher) was used to permit a rapid onset of growth. In each fermentation, $\mathrm{pH}$ was controlled at a different preset lower 


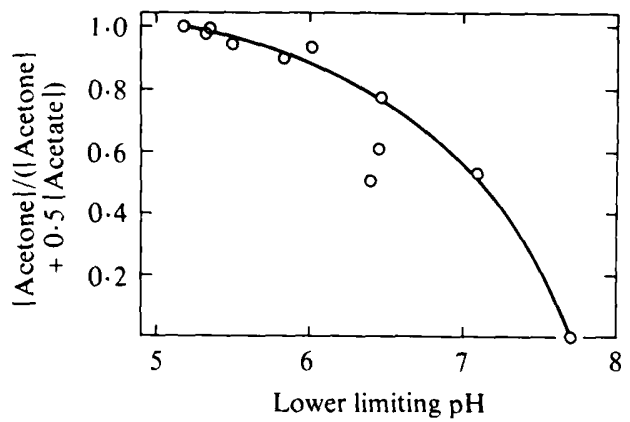

Fig. 2. Effect of lower limiting culture $\mathrm{pH}$ on the conversion of acetate to acetone by $B$. macerans ATCC 7068. Each point represents a separate fermenter run.

Table 3. Production of ${ }^{14} \mathrm{CO}_{2}$ by $\mathrm{B}$. macerans from $\left[{ }^{14} \mathrm{Clglucose}\right.$ labelled in various carbon atoms Cultures were grown in CM5 medium containing $0.5 \%$ glucose and $0.2 \%$ yeast extract.

\begin{tabular}{crrr}
$\begin{array}{l}\text { Position of }{ }^{14} \mathrm{C}- \\
\text { label in glucose }\end{array}$ & $\begin{array}{c}\text { Glucose } \\
\text { [d.p.m. }\left(\mu \mathrm{gg} \text {-atom C) }{ }^{-1}\right]^{*}\end{array}$ & \multicolumn{1}{c}{$\mathrm{CO}_{2}$} & Ratio \\
C-1 & 12687 & 404 & 0.032 \\
C-3,4 & 3153 & 2169 & 0.687 \\
C-6 & 12295 & 26 & 0.002
\end{tabular}

- d.p.m. ( $\mu$ g-atom C) $)^{-1}$ for glucose equals d.p.m. ( $\mu$ g-atom C) $)^{-1}$ for $\left[1-^{-14} \mathrm{C}\right]$ glucose or $\left[6^{-14} \mathrm{C}\right]$ glucose and $0.5 \times$ d.p.m. $\left(\mu \mathrm{g}\right.$-atom $\mathrm{C}^{-1}$ for $\left[3,4^{-14} \mathrm{C}\right] \mathrm{glucose}$.

$\dagger$ Ratio of specific radioactivity of $\mathrm{CO}_{2} /$ specific radioactivity $(\mathrm{C} \text { atom glucose) })^{-1}$.

limiting value by automatic addition of $\mathrm{NaOH}$. Samples withdrawn at intervals over a $4 \mathrm{~d}$ period were analysed for substrate and product concentrations. Two ratios were calculated to characterize carbon flux in the fermentations. The first ratio

$$
\text { [acetone]/([acetone] }+0 \cdot 5[\text { acetic acid] })
$$

provided a measure of the extent of acetate conversion to acetone. The second ratio

$$
\text { [ethanol] } /([\text { ethanol }]+[\text { acetic acid] }+2 \text { [acetone }])
$$

provided a measure of the relative conversion of the presumed intermediate acetyl-CoA to ethanol, versus the total conversion of acetyl-CoA to all products. For each fermentation, both ratios reached equilibrium values after approximately $50-60 \mathrm{~h}$ of incubation, and did not change significantly upon further incubation.

The extent of conversion of acetic acid to acetone increased with decreasing lower limiting $\mathrm{pH}$, with no distinct break point in the curve (Fig. 2). At $\mathrm{pH}$ values of $\leqslant 5 \cdot 2$, no residual acetate remained in the broth.

By contrast, the relative conversion of acetyl-CoA to ethanol was independent of the lower limiting $\mathrm{pH}$ value, and varied within the range $0.53-0.73$ (mean value \pm S.E.M. $=0.63 \pm 0.06$ ). The molar ratio of ethanol produced per glucose fermented was also independent of the lower limiting $\mathrm{pH}$ value, and varied within the range $0.95-1 \cdot 34$ (mean value \pm S.E.M. $=1 \cdot 11 \pm 0 \cdot 15$ ).

\section{Glucose fermentation pathway}

Elucidation of the glucose fermentation pathway in $B$. macerans was achieved by determination of specific radioactivity of ${ }^{14} \mathrm{CO}_{2}$ formed from $\left[{ }^{14} \mathrm{C}\right]$ glucose labelled in different carbon atoms (Table 3). More than two-thirds of the $\mathrm{CO}_{2}$ arose from the $\mathrm{C}-3$ and $\mathrm{C}-4$ positions of glucose, while the $\mathrm{C}-1$ and $\mathrm{C}-6$ positions contributed only $3 \%$ and $0 \cdot 2 \%$ of the $\mathrm{CO}_{2}$, respectively. 
Table 4. Enzyme activities in extracts of B. macerans cells harvested in exponential $(16 \mathrm{~h})$ and stationary $(46 \mathrm{~h})$ growth phases

$\begin{array}{lccc}\text { Enzyme } & \text { Assay } \mathrm{pH} & \overbrace{\begin{array}{c}16 \mathrm{~h} \\ \text { Cultures }\end{array}} & \begin{array}{c}46 \mathrm{~h} \\ \text { Cultures }\end{array} \\ \text { Formate dehydrogenase } & 5 \cdot 7 & 15 & 47 \\ \text { [nmol min } & \text { Specific enzyme activity } \\ \text { Pyruvate formate-lyase } & 7 \cdot 0 & 8 & 18 \\ \text { Pyruvate dehydrogenase } & 7 \cdot 0 & 276 & 300 \\ & 5 \cdot 7 & 0 & 0 \\ & 7 \cdot 0 & 3 & 2\end{array}$

\section{Growth yields}

Exponential-phase cultures which had consumed 1.09 and $5.23 \mathrm{~g}$ glucose $1^{-1}$ exhibited an increase in cell dry weight of 147 and $746 \mathrm{mg} \mathrm{l}^{-1}$, respectively. Thus, calculated molar growth yields were 24.3 and $25.7 \mathrm{~g}$ cells (mol glucose) ${ }^{-1}$, respectively.

\section{Effect of gas phase on growth}

Growth of B. macerans ATCC 7068 in sealed tubes or bottles containing unreduced medium was accompanied by reduction of added resazurin indicator during the first few hours of growth, regardless of initial gas phase $\left(\mathrm{N}_{2}, \mathrm{CO}_{2}\right.$, or air). In fermenter culture, this strain grew well in media gassed continuously with $\mathrm{N}_{2}$, or if previously gassed with $\mathrm{N}_{2}$ and incubated without gassing. However, no growth was observed during gassing with air. Cells growing under $\mathbf{N}_{2}$ ceased growth upon initiation of air-sparging. Similarly, cultures streaked on to plates of CM5/ glucose agar grew when incubated under $\mathrm{N}_{2}$, but grew poorly under air. Addition of reducing agents $\left(0.5 \mathrm{~g} \mathrm{l}^{-1}\right.$ each $\mathrm{Na}_{2} \mathrm{~S} .9 \mathrm{H}_{2} \mathrm{O}$ and cysteine. $\left.\mathrm{HCl}\right)$ did not alter the rate or extent of growth, substrate consumption, or product formation relative to control cultures without added reducing agent. Similar product balances were obtained with $\mathrm{He}$ and $\mathrm{N}_{2}$ gas phases. However, incubation under $1 \mathrm{~atm} \mathrm{H}_{2}$ resulted in ethanol/acetone ratios of $6.2 \pm 0.4$, compared to $3.9 \pm 0.5$ for $\mathrm{He}$ and $3.9 \pm 0.4$ for $\mathrm{N}_{2}$.

\section{Enzyme activities in cell extracts}

Enzyme activities for the metabolism of pyruvate and formate in cell extracts of $B$. macerans are shown in Table 4. Extracts contained an active pyruvate formate-lyase which required reducing conditions (e.g. $5 \mathrm{~mm}$-DTT). Extracts also contained a formate dehydrogenase activity which utilized methyl viologen, but not NAD, NADP or ferredoxin as electron acceptor. Pyruvate dehydrogenase was detected only in trace quantities, and displayed similar responses to different electron carriers as did the formate dehydrogenase activity. The above enzymes displayed similar activities in extracts prepared from cells grown to either exponential or stationary phase. No activity was observed for lactate dehydrogenase (in either direction, using $\mathrm{NAD}(\mathrm{P})$ as electron carrier) or hydrogenase (using methyl viologen, benzyl viologen, NAD(P) or ferredoxin as electron acceptors).

\section{DISCUSSION}

Glucose fermentation by $B$. macerans ATCC 7068 was marked by two distinct metabolic phases, the primary phase characterized by cell growth and the formation of ethanol, acetic acid, and formic acid, and the secondary phase marked by continued ethanol production, conversion of acetate to acetone, and conversion of formate to $\mathrm{H}_{2}$ and $\mathrm{CO}_{2}$ (Fig. 1). The secondary phase appeared to be induced by events related to achievement of a low culture $\mathrm{pH}$, as product ratios were related to the lower limiting culture pH (Fig. 2). Although the preferential production of ethanol in the presence of $\mathrm{CaCO}_{3}$ (Table 2) may have been due in part to inhibition of acetone formation by increased amounts of $\mathrm{CO}_{2}$, the observation that similar elevations in the ethanol/ 


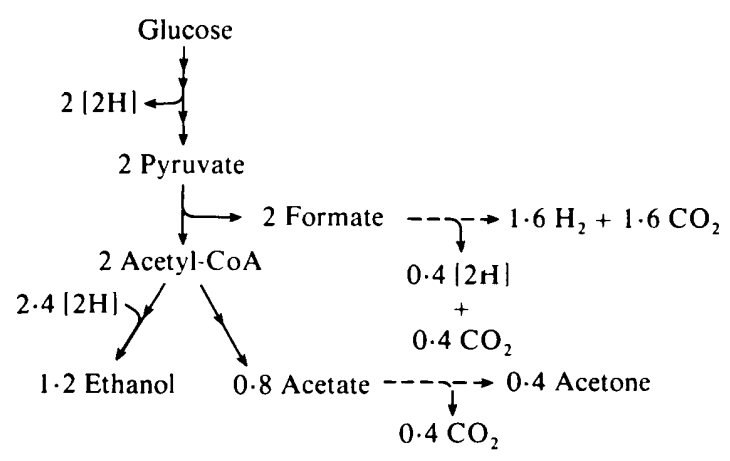

Fig. 3. Glucose fermentation pathway of $\boldsymbol{B}$. macerans growing under anaerobic conditions. Pyruvate formation via the Embden-Meyerhof pathway was determined by use of $\left[{ }^{14} \mathrm{C}\right]$ glucose labelled in different carbon atoms. Other reactions were inferred from fermentation balances and from enzyme assays in cell extracts. Reactions involved in conversion of acetate to acetone remain to be elucidated, as do the in vivo electron carriers involved in oxidoreductase reactions. The stoichiometries are estimates based on attainment of a low culture $\mathrm{pH}$, with subsequent complete conversion of acetate and formate to their respective products. Broken arrows indicate reactions which occur predominantly after exponential cell growth has been completed. Pyruvate dehydrogenase and pyruvate decarboxylase are not considered to be of quantitative importance in this generalized pathway.

acetone ratio were obtained with other $\mathrm{pH}$ control agents (e.g. $\mathrm{NaOH}$ ) suggests that $\mathrm{CaCO}_{3}$ preferentially enhanced ethanol production as a result of $\mathrm{pH}$ control. These data are in general agreement with those of other workers (Northrop et al., 1919; Arzberger et al., 1920; Speakman, 1925).

The product stoichiometries and the fate of specifically labelled $\left[{ }^{14} \mathrm{C}\right]$ glucose (Table 3 ) suggest a glucose fermentation pathway for this organism as shown in Fig. 3. Glucose is catabolized primarily by the Embden-Meyerhof pathway to yield pyruvate, which may then be converted via acetyl-CoA to ethanol, acetate, and, ultimately, acetone.

The transient appearance of acetate prior to acetone production, along with the enhanced production of acetone observed upon addition of acetate, suggests that acetate is an intermediate in acetone formation. The fractions of $\mathrm{CO}_{2}$ derived from the $\mathrm{C}-1, \mathrm{C}-3,4$ and $\mathrm{C}-6$ positions of glucose yield a combined total of only 0.72 , indicating that a significant portion of the total $\mathrm{CO}_{2}$ is derived from the C-2 and C-5 positions of glucose and perhaps from yeast extract. The data suggest that acetone synthesis in this organism proceeds in a manner similar to that suggested for C. acetobutylicum, via stationary phase condensation of acetate-derived two-carbon units with subsequent decarboxylation to yield acetone (Johnson et al., 1933; Wood et al., 1945). The specific sequence of enzyme reactions which mediate the conversion of acetate to acetone, however, remains to be elucidated.

Production of $\mathrm{H}_{2}$ from glucose by $B$. macerans apparently proceeded primarily via a formate intermediate. This is suggested firstly by the appearance of formate during exponential growth, and its subsequent disappearance in older cultures as $\mathrm{H}_{2}$ and $\mathrm{CO}_{2}$ are evolved; secondly, by the conversion of added formate to stoichiometric amounts of $\mathrm{H}_{2}$ and $\mathrm{CO}_{2}$ by cells growing on glucose; and thirdly, by the presence of an active pyruvate formate-lyase but only a very low level of pyruvate dehydrogenase in cell extracts.

Although a methyl viologen-linked formate dehydrogenase was demonstrated in cell extracts of $B$. macerans, attempts to measure $\mathrm{H}_{2}$ evolution from formate in the presence of a variety of added electron carriers was unsuccessful, even when a sensitive polarographic assay for $\mathrm{H}_{2}$ was employed. Hamilton \& Wolfe (1959) have shown that resting cells of $B$. macerans produce $\mathrm{H}_{2}$ from pyruvate or formate, but that cell extracts lacked this capacity despite the presence of an active pyruvate-formate exchange reaction. It is likely that a formic hydrogen lyase system similar to that in other facultative anaerobes (i.e., a formate dehydrogenase and hydrogenase complex which utilizes electron carriers other than pyridine nucleotides or ferredoxin) may 
operate in B. macerans (Gray \& Gest, 1968). The inability to detect the formic hydrogen lyase activity, suggested for $B$. macerans by the above physiological data, is probably due to the lack of the proper electron carriers in the diluted assay mixture. Gray \& Gest (1968) have proposed that the low-potential $c$-type cytochromes involved in formate metabolism in other facultative anaerobes are not involved in $B$. macerans, due to the apparant inability of this organism to produce cytochromes during anaerobic growth.

The fermentation product ratios observed here indicate that $B$. macerans produces up to $1 \cdot 3$ ethanol per glucose fermented and converts over $50 \%$ of its acetyl-CoA to ethanol. These ratios suggest that reducing equivalents for ethanol synthesis are derived not only from oxidation of glucose to pyruvate, but also from metabolism of pyruvate or its subsequent products, formate and $\mathrm{H}_{2}$. Although exogenous $\mathrm{H}_{2}$ results in an increased ethanol yield during glucose fermentation in a closed system, this may be the result of end-product inhibition of hydrogenase with a consequent channelling of electrons from oxidation of pyruvate or formate to coenzymemediated ethanol production. Pyruvate as a direct source of reducing equivalents in ethanol production would require an active pyruvate dehydrogenase activity. Although cell extracts of $B$. macerans have been shown to catalyse a pyruvate- $-\mathrm{CO}_{2}$ exchange reaction (Hamilton \& Wolfe, 1959), the current investigation revealed only traces of methyl viologen-linked pyruvate dehydrogenase, which could be a result of combined activities of pyruvate formate-lyase and formate dehydrogenase. Reducing equivalents for ethanol production might also be obtained from formate via a formate dehydrogenase reaction normally associated with the formic hydrogen lyase complex. Resolution of these possibilities will be aided by elucidation of the currently unidentified in vivo electron carriers for the relevant dehydrogenases (ethanol, formate, and possibly pyruvate dehydrogenases) in this organism.

An alternative hypothesis which explains the excess ethanol production is that a small portion of the pyruvate is metabolised via a pyruvate decarboxylase (EC 4.1.1.1) to produce $\mathrm{CO}_{2}$ and acetaldehyde. The requirements for reducing equivalents to convert acetaldehyde to ethanol could then be met by the reduced pyridine nucleotides generated during conversion of glucose to pyruvate. However, metabolism of pyruvate in this manner proceeds without $\mathrm{H}_{2}$ formation due to the unfavourable thermodynamics for conversion of reduced pyridine nucleotides (the only available source of electrons) to $\mathrm{H}_{2}$. In contrast, $B$. macerans produced approximately $1.8 \mathrm{H}_{2}$ per glucose fermented, indicating that at least $90 \%$ of the pyruvate is catabolized via reactions which yield reduced products suitable for oxidation to $\mathrm{H}_{2}$ (i.e., mediated by pyruvate formatelyase and/or pyruvate dehydrogenase). Although a thiamine pyrophosphate-dependent pyruvate decarboxylase was not detected in cell extracts, the possibility of a minor involvement of this enzyme in pyruvate metabolism cannot be excluded by the data presented here.

It is instructive to compare the anaerobic glucose catabolism of $B$. macerans with that of two bacterial types which it most closely resembles, $C$. acetobutylicum and certain facultative anaerobes such as Escherichia coli. Both $B$. macerans and $C$. acetobutylicum are endosporeforming rods which produce a reduced, neutral solvent as the chief non-gaseous product, and acetone, $\mathrm{H}_{2}$, and $\mathrm{CO}_{2}$ as co-products (Prescott \& Dunn, 1959). In both organisms, acetone formation occurs only during secondary metabolism, from acetate produced during the primary growth phase. There are, however, several important differences in the fermentative metabolism of these two organisms. Reducing equivalents generated during carbohydrate fermentation are disposed of as ethanol by $B$. macerans, and primarily as n-butanol and $n$ butyrate by $C$. acetobutylicum. The inability of $B$. macerans to produce n-butanol or n-butyrate during carbohydrate fermentation, or to reduce exogenous n-butyrate or n-butanal, suggests that this organism lacks the enzymes of the butanol pathway. Both organisms produce acetone only at low $\mathrm{pH}$. However, while induction of acetone and $\mathrm{n}$-butanol synthesis in C. acetobutylicum can be achieved by addition of acetate plus n-butyrate (total concentration $10 \mathrm{~mm}$ ) to cultures maintained at pH 5.0 (Gottschal \& Morris, 1981), addition of approximately $60 \mathrm{~mm}$-acetate at pH 4.9-6.0 was not successful in hastening acetone synthesis in $B$. macerans.

Pyruvate metabolism and $\mathrm{H}_{2}$ production in $B$. macerans resembles that of other facultative anaerobes (Gray \& Gest, 1968). Pyruvate is cleaved by a pyruvate formate-lyase reaction to yield formate, which is subsequently oxidized by a formate dehydrogenase. Most of the reducing 
equivalents thus generated are used in $\mathrm{H}_{2}$ production, probably by a hydrogenase associated with a formic hydrogen lyase complex. Some of the reducing equivalents, however, appear to be utilized in other reductive reactions, especially ethanol production (Fig. 3). Pyruvate dehydrogenase appears to be of little importance in this organism. A direct comparison of pyruvate metabolism in $B$. macerans and $C$. acetobutylicum is not possible, owing to a lack of data on the latter system. Most Clostridium species catabolize pyruvate via a ferredoxin-linked pyruvate dehydrogenase to yield acetyl- $\mathrm{CoA}, \mathrm{CO}_{2}$, and reduced ferredoxin, without the involvement of a formate intermediate (Gray \& Gest, 1968; Hugo et al., 1972; Thauer et al., 1977). In this case, reduced ferredoxin is either used directly for $\mathrm{H}_{2}$ production or is oxidized via a NAD/ferredoxin oxidoreductase to generate reduced electron carriers for other reductions (Thauer et al., 1977). However, several Clostridium species contain both pyruvate dehydrogenase and pyruvate formate-lyase activities. The function of the latter, freely-reversible enzyme is thought to be either solely anabolic, as in C. kluyveri (Thauer et al., 1972), or both anabolic and catabolic, as in C. butyricum (Thauer et al., 1970). Pyruvate formate-lyase is also found in $C$. butylicum (Thauer et al., 1972), a species which differs from C. acetobutylicum primarily in its ability to further reduce acetone to isopropanol.

I thank T. F. Harris for technical assistance, D. Van Dyk for assistance in polarography, and W. Kenealy for helpful discussions. This report is contribution no. 3240 from the Central Research and Development Department.

\section{REFERENCES}

Arzberger, C. F., Peterson, W. H. \& Fred, E. B. (1920). Certain factors that influence acetone production by Bacillus acetoethylicum. Journal of Biological Chemistry 44, 465-479.

BALCH, W. E. \& WolfE, R.S. (1976). New approach to the cultivation of methanogenic bacteria : 2-mercaptoethanesulfonic acid (HS-CoM)-dependent growth of Methanobacterium ruminantium in a pressurized atmosphere. Applied and Environmental Microbiology 32, 781-791.

Gordon, R. E., Haynes, W. C. \& Hor-Nay Pang, C. (1973). The genus Bacillus. In Agriculture Handbook No. 427, pp. 202. Washington, D.C.: Agricultural Research Service, United States Department of Agriculture.

GotTSCHAL, J. C. \& MORRIS, J. G. (1981). The induction of acetone and butanol production of Clostridium acetobutylicum by elevated concentrations of acetate and butyrate. FEMS Microbiology Letters 12, 385-389.

GRAY, C. T. \& GEST, H. (1968). Biological formation of molecular hydrogen. Science 148, 186-192.

Hamilton, R. D. \& Wolfe, R. S. (1959). Pyruvate exchange reactions in Bacillus macerans. Journal of Bacteriology 78, 253-258.

Hugo, H. V., Schoberth, S., Madan, V. K. \& GotTschalK, G. (1972). Coenzyme specificity of dehydrogenases and fermentation of pyruvate by Clostridia. Archiv für Mikrobiologie 87, 189-202.

Johnson, M. J., Peterson, W. H. \& Fred, E. B. (1933). Intermediary compounds in the acetonebutyl alcohol fermentation. Journal of Biological Chemistry 101, 145-157.

Miller, G. L., Blum, R., Glennon, W. E. \& Burton, A. L. (1960). Measurement of carboxymethylcellulase activity. Analytical Biochemistry 1, 127132.

Nelson, D. R. \& Zeikus, J. G. (1974). Rapid method for the radioisotopic analysis of gaseous products of anaerobic metabolism. Applied Microbiology 28, 258-261.

Northrop, J. H., ASHe, L. H. \& SENIOR, J. K. (1919). Biochemistry of Bacillus acetoethylicum with reference to the formation of acetone. Journal of Biological Chemistry 39, 1-21.

Prescott, S. C. \& DUNN, C. G. (1959). Industrial Microbiology, 3rd edn, pp. 285-298. New York: McGraw-Hill.

SCHARDINGER, F. (1905). Bacillus macerans, ein acetonbildender Rottebacillus. Zentralblatt für Bakteriologie, Parasitenkunde, Infektionskrankheiten und Hygiene (Abteilung II) 14, 772-781.

SPEAKMAN, H. B. (1925). The biochemistry of acetone formation from sugars by Bacillus acetoethylicum. Journal of Biological Chemistry. 64, 41-52.

SWeet, W. J., Houchins, J. P., Rosen, P. R. \& ARP, D. J. (1980). Polarographic measurement of $\mathrm{H}_{2}$ in aqueous solutions. Analytical Biochemistry 107, 337340.

Thauer, R. K., Rupprecht, E. \& JungermanN, K. (1970). The synthesis of one-carbon units from $\mathrm{CO}_{2}$ via a new ferredoxin-dependent monocarboxylic acid cycle. FEBS Letters 8, 304-307.

ThaUer, R. K., Kirchniawy, F. H. \& JUngermanN, K. A. (1972). Properties and function of the pyruvate-formate-lyase in clostridia. European Journal of Biochemistry 27, 282-290.

Thauer, R. K., Jungermann, K. \& Decker, K. (1977). Energy conservation in chemotrophic anaerobic bacteria. Bacteriological Reviews 41, 100-180.

WOOD, H. G., Brown, R. W. \& WERKMAN, C. H. (1945). Mechanism of the butyl alcohol fermentation with heavy carbon acetic and butyric acids and acetone. Archives of Biochemistry 6, 243-260.

WOOD, W. A. (1961). Fermentation of carbohydrates and related compounds. In The Bacteria, vol. 2 . Edited by I. C. Gunsalus \& R. Y. Stanier, pp. 59149. New York: Academic Press 